\title{
Quantifying suitable habitat of the threatened western prairie fringed orchid
}

\author{
PAIGE M. WOLKEN, CAROLYN HULL SIEG, AND STEPHEN E. WILLIAMS
}

Authors are botanist, U.S. Fish and Wildlife Service, Utah Field Office, 145 East 1300 South, Suite 404, Salt Lake City, UT 84115; research plant ecologist, USDA Forest Service Rocky Mountain Research Station, 2500 S. Pine Knoll Drive, Flagstaff, Ariz. 86001; and dean of the Graduate School, University of Wyoming, Laramie, Wyoming 82071. At the time of the research, Wolken was graduate student, Department of Plant, Soil, and Insect Sciences, University of Wyoming, Laramie, Wyo., 82071; Sieg was research wildlife biologist, USDA Forest Service Rocky Mountain Research Station, Rapid City, S.D.; and Williams was professor and Department Head, Department of Plant, Soil, and Insect Sciences, University of Wyoming, Laramie, Wyo. Carolyn's e-mail address is csieg@theriver.com

\begin{abstract}
Land managers need accurate and quick techniques to identify suitable habitat of species of interest. For species protected by federal or state laws, identification of suitable habitat is critical for developing a conservation strategy that includes reestablishing populations and altering management to address this need. In this research, we quantified vegetative and edaphic habitat of the western prairie fringed orchid (Platanthera praeclara Sheviak and Bowles), a federally listed threatened plant. Lowlands (swales) that supported orchids in our southeastern North Dakota study area were characterized as having a higher soil moisture content within the top $10 \mathrm{~cm}$, when compared to swales devoid of orchids. The vegetative composition of orchid-supporting swales reflected this higher moisture content. These data were then used in developing a logistic regression model to differentiate suitable habitat. The model correctly classified $84 \%$ of 38 swales as either orchid-supporting or non-orchid-supporting using 4 variables: percent canopy cover of Baltic rush (Juncus balticus Willd.) and hedge-nettle (Stachys palustris L.), soluble soil magnesium and August surface soil moisture. Land managers can use this model to rapidly assess the suitability of a site in this ecoregion for the orchid. By collecting data on the cover of just Baltic rush, which would take about 45 minutes, and entering it in the equation, a land manager could correctly classify $66 \%$ of the orchid swales as either suitable or unsuitable as orchid habitat. This approach, because it incorporates quantitative data and allows managers to rapidly and accurately identify suitable habitats, shows promise for other plant species.
\end{abstract}

Key Words: Platanthera praeclara; wetland; tallgrass prairie; threatened plant; edaphic factors; logistic regression; soil moisture; North Dakota.

Land managers need quantitative techniques to rapidly assess the suitability of habitats for rare plant species. This information

We thank the staff of the Custer National Forest for their cooperation and support. Larry Potts, Bernadette Braun and Steve Schumacher of the Sheyenne Ranger District were particularly helpful during the field seasons. We thank Dr. Dennis H. Knight, University of Wyoming; Dr. Charles E. Umbanhower, Jr., St. Olaf College; Marlin Bowles, Morton Arboretum; and J. Stephen Shelly, U.S. Forest Service, for their review of an earlier draft of this manuscript. Rudy King, Station Biometrician, Rocky Mountain Research Station, assisted us with the statistics and Jose Iniquez translated our abstract.

Manuscript accepted 4 Nov. 00.

\section{Resumen}

Los administradores de tierras necesitan tecnicas precisas y rapidas para identificar habitat adecuado de especies de interes. Para especies protegidas por leyes federales o estatales, la identificacion de habitat adecuado es critico para desarrollar una estrategia de conservacion que incluya el reestablecimiento de poblaciones y adecuar el manejo de acuerdo a estas necesidades. En esta investigacion, cuantificamos el habitat vegetativo y edafico de la orquidia del borde de la pradera oriental (Platanthera praeclara Sheviak and Bowle), una planta enlistado federalmente como amenazada. Tierras inundables (cienegas) que soportan estas orquideas en nuestra area de estudio en el sureste de North Dakota fueron caracterizadas como de mas alto contenido de humedad en los primeros $10 \mathrm{~cm}$ del suelo, cuando se comparan con las cienegas sin orquideas. La composicion vegetal de las cienegas que soportan orquideas reflejan este mas alto contenido de humedad. Estos datos fueron usados para desarollar un modelo de regresion logistica para diferenciar habitat adecuado. El modelo clasifico correctamente el $84 \%$ de 38 cienegas como adecuados o inadecuados para las orquideas usando cuatro variables: porcentajes de coberturas de junco Baltico (Juncus balticus Wiilld.) y ortiga (Stachys palustris L.), magnesio soluble en el suelo y humedad superficial del suelo en Agosto. Administradores de tierras pueden usar este modelo para evaluar rapidamente la aptitud de un sitio para las orquideas en esta ecoregion. Colectando datos de cobertura solamente de junco Baltico, que tomaria cerca de 45 minutos, y metiendolos en la ecuacion, un administrador podria clasificar correctamente un $66 \%$ de cienegas como habitat adecuadas o inadecuadas para orquideas. Este enfoque, porque incorpora datos cuantitativos y permite a los administradores identificar habitat adecuado con rapidez y precision, parece prometedor para otras especies de plantas.

may be used to delineate special management areas or to identify potential reintroduction sites. Establishment of new populations is imperative for the recovery and eventual delisting of threatened and endangered plant species (Schemske et al. 1994). Success of establishment efforts is greatest when individuals are replanted in the same microhabitat from which they were collected (Holsinger and Gottlieb 1991).

The western prairie fringed orchid (Platanthera praeclara Sheviak and Bowles) was listed as a threatened plant in 1989 
(U.S. Fish and Wildlife Service 1989). Its rarity is attributed to the conversion of most of the tallgrass prairie to croplands or other development (Samson and Knopf 1994). Currently, only 3 metapopulations of the orchid are known: 2 in the United States and 1 in Manitoba (U.S. Fish and Wildlife Service 1996). The North Dakota metapopulation is in the southeastern corner of the state, almost entirely on the Sheyenne National Grassland, in sedge meadows associated with lowland depressions (swales) (Sheviak and Bowles 1986, Bjugstad and Fortune 1989, Sieg and Bjugstad 1994). Although many subirrigated swales on the Sheyenne National Grassland support populations of the western prairie fringed orchid, there are also swales that do not support orchids. The objectives of this study were to: 1) isolate vegetative and edaphic factors associated with the patchy distribution of the western prairie fringed orchid, and 2) develop a technique (model) that can be used to differentiate between suitable and unsuitable habitat.

\section{Materials and Methods}

A paired design was chosen to compare environmental factors between swales that supported orchids and swales that did not. Using baseline data collected over the previous 7 years, 19 swales with a minimum of 10 orchids each were selected from the core of the Sheyenne National Grassland metapopulation. In addition, for each swale supporting orchids, we selected a nearby swale without orchids, for a total of 19 non-orchid swales. Criteria used in selecting non-orchid swales included close proximity to an orchid swale and similar management, exposure and topography. Potential non-orchid sites were searched carefully for orchids-including the smaller vegetative plants - to ensure that the site was devoid of orchids. We attempted to cover the range of swale environments exposed to a seed source and therefore potentially capable of supporting the orchid. We established an oblong or circular plot in each of the 38 swales that, depending on the size and shape of the swale and distribution of the orchid population, ranged in size from 250 to $500 \mathrm{~m}^{2}$. The plots were dispersed among 6 study sites on the Sheyenne National Grassland. Two thirds of the plots were grazed by cattle either season long or were in a three-pasture rotation system. The remainder of the plots were in exclosures or along the railroad right-of-way.
In July 1992, plant composition in orchid and non-orchid swales was characterized by estimating percent plant canopy cover in a minimum of 20 and up to fifty, $20 \times 50 \mathrm{~cm}$ quadrats. Cover was estimated to fall in 1 of 6 cover classes $(1=0-5 \%, 2$ $=6-25 \%, 3=26-50 \%, 4=51-75 \%, 5=$ $76-95 \%$, and $6=96-100 \%$ ) (Daubenmire 1959). Quadrats were systematically placed at 1-m intervals along permanent transects (20 to $50 \mathrm{~m}$ in length). Variables estimated included: total plant canopy cover, total graminoid cover, total shrub cover, total forb cover, litter, bare ground, and cover by species. We used Great Plains Flora Association (1986) for taxonomic determination and nomenclature. During the height of the flowering season (late June through early July) in 1992 and 1993, orchids were permanently marked with numbered marker pins and mapped using a coordinate system.

Soil moisture was estimated in July and August of 1992 and June of 1993. A probe (48 cm long x $2 \mathrm{~cm}$ diameter tube) was used to collect 4 soil samples per swale. Each sample was stratified into 4 depths: 0-2 cm, 2-10 cm, 10-20 cm, and 20-30 $\mathrm{cm}$. Samples were collected $15 \mathrm{~cm}$ from 4 separate orchid plants in orchid swales and randomly in non-orchid swales. Soil moisture was determined gravimetrically (dried at $105^{\circ} \mathrm{C}$ for 48 hours). In 1993, soils were completely saturated due to flooding. Therefore, depth of standing water was measured at 4 random points in each swale in July and August of 1993.

Additional soil samples were collected in August 1992 for chemical analyses. A total of 4 samples $(10 \mathrm{~cm}$ deep by $4 \mathrm{~cm}$ diameter) were collected 15 to $20 \mathrm{~cm}$ from 4 separate orchid plants in each orchid swale and randomly in each non-orchid swale. Approximately $700 \mathrm{~g}$ of soil was taken per sample, stored in plastic bags and frozen for subsequent total nitrogen testing. Chemical analyses, conducted at the University of Wyoming Soil Testing Laboratory,Laramie, Wyo. included $\mathrm{pH}$, electrical conductivity (EC), soluble cations: potassium $(\mathrm{K})$, sodium $(\mathrm{Na})$, magnesium $(\mathrm{Mg})$, calcium $(\mathrm{Ca})$, and soluble sulfur (S), percent calcium carbonate $\left(\mathrm{CaCO}_{3}\right)$ (Richards 1954$)$, percent total nitrogen $(\mathrm{N})$ (Jones 1971), nitrate $\left(\mathrm{NO}_{3}\right)$ (Sims and Jackson 1971), available phosphate phosphorous $\left(\mathrm{PO}_{4}\right)(\mathrm{Olsen}$ and Sommers 1982), percent organic matter (OM) (Greweling and Peech 1960), percent water at saturation, and texture (mechanical) (Day 1965).

\section{Statistical Analysis}

We designed the study to use paired ttests to test for differences in vegetative composition, soil moisture, water depth, and soil chemistry between orchid and non-orchid swales. Assumptions of normality were tested with Lilliefors Test; the variances were tested using the Levene Test (Norusis 1990). The data for 42 of 51 variables were not normally distributed $(\mathrm{P}$ $<0.05)$. Elimination of extreme outliers and data transformation did not correct non-normality nor heterogeneous variances. Therefore, we used the Wilcoxon signed-rank test to compare variables between orchid and non-orchid swales. Significance of Wilcoxon signed-rank tests was estimated using Monte Carlo estimates of exact P-values based on 10,000 repeated samples, thus avoiding the assumptions attached to using the asymptotic P-values (Mehta and Patel 1995). We set $\alpha=0.05$ for all tests.

We utilized logistic regression to identify variables that are most useful or "most likely" to distinguish between two classes (Press and Wilson 1978, Hosmer and Lemeshow 1989). Logistic regression provides an equation to predict the probability that a swale will support orchids and a multivariate comparison between orchid and non-orchid swales, plus it identifies those variables most associated with the presence and absence of orchids. The selection and contribution of each variable depends on the other variables in the model, so highly correlated variables may greatly influence the final model. We used a correlation matrix to identify these variables. Only 1 of a pair of highly correlated $(r>0.85)$ variables was used in the model; the variable with the least biological importance was eliminated. We applied forward stepwise logistic regression with the likelihood-ratio test. Misclassification rates for logistic regression models were estimated using "leave-one-out" cross-validation, which makes more efficient use of small data sets that are common in studies of rare species. This cross-validation method involves refitting the model by leaving 1 observation out, and then computing the predicted value for the $i$ th observation; this is done for each observation at each step and then the average cross-validation sum of squares is computed (Efron and Tibshirani 1993). We summarized the average misclassification rate for orchid and non-orchid sites at each step. We used the SPSS/PC+ statistical package (Norusis 1990) to perform all analyses. 
Table 1. Average ( \pm SD) percent canopy cover of major plant species in orchid and non-orchid swales on the Sheyenne National Grassland, 1992.

\begin{tabular}{|c|c|c|}
\hline \multirow{2}{*}{$\begin{array}{l}\text { Category } \\
\text { Species }\end{array}$} & \multicolumn{2}{|c|}{ Swale Type } \\
\hline & Orchid & Non-orchid \\
\hline & $-\cdots-\cdots($ & $\cdots \ldots$ \\
\hline Total Cover & $83.7 \pm 8.7$ & $82.4 \pm 5.3$ \\
\hline Total Litter & $93.9 \pm 4.2$ & $89.2 \pm 12.5$ \\
\hline Bare ground & $1.5 \pm 2.1$ & $5.5 \pm 8.2$ \\
\hline Total Forb Cover & $41.4 \pm 15.7$ & $33.9 \pm 15.8$ \\
\hline western ragweed (Ambrosia psilostachya DC.) & $4.7 \pm 6.4$ & $6.1 \pm 5.9$ \\
\hline meadow anemone (Anemone canadensis L.) & $6.7 \pm 10.7$ & $2.8 \pm 3.5$ \\
\hline panicled aster (Aster simplex Willd.) & $7.6 \pm 8.7$ & $4.0 \pm 3.8$ \\
\hline smooth scouring rush (Equisetum laevigatum $\mathrm{A}$. Br.) & $1.4 \pm 2.4$ & $1.2 \pm 1.5$ \\
\hline leafy spurge (Euphorbia esula L.) & $5.2 \pm 10.0$ & $2.9 \pm 4.6$ \\
\hline euthamia (Euthamia graminifolia (L.) Nutt.) & $1.8 \pm 3.5$ & $2.2 \pm 3.1$ \\
\hline wild strawberry (Fragaria virginiana Duchn.) & $4.3 \pm 7.0$ & $4.3 \pm 9.5$ \\
\hline wild licorice (Glycyrrhiza lepidota Pursh) & $0.7 \pm 1.0^{*}$ & $4.4 \pm 6.5$ \\
\hline water smartweed (Polygonum amphibium L.) & $1.3 \pm 2.6$ & $0.8 \pm 1.6$ \\
\hline Canada goldenrod (Solidago canadensis L.) & $2.8 \pm 2.9$ & $3.2 \pm 4.4$ \\
\hline hedge-nettle (Stachys palustris L.) & $1.0 \pm 1.8^{* *}$ & $0.0 \pm 0.0$ \\
\hline Total Graminoid Cover & $65.8 \pm 20.2$ & $66.9 \pm 14.6$ \\
\hline big bluestem (Andropogon gerardii Vitman) & $0.1 \pm 0.3$ & $3.7 \pm 9.4$ \\
\hline little bluestem (Schizachyrium scorparium Michx.) Nash & $0.0 \pm 0.0$ & $1.9 \pm 8.5$ \\
\hline northern reedgrass (Calamagrostis stricta (Timm.) Koel.) & $14.7 \pm 18.7$ & $6.9 \pm 8.6$ \\
\hline $\begin{array}{l}\text { Wilcox dicanthelium (Dichanthelium wilcoxianum (Vasey) } \\
\text { Freckmann) }\end{array}$ & $3.3 \pm 8.6$ & $1.5 \pm 2.3$ \\
\hline Baltic rush (Juncus balticus Willd.) & $5.4 \pm 5.1 * *$ & $1.7 \pm 1.9$ \\
\hline switchgrass (Panicum virgatum L.) & $6.2 \pm 6.6$ & $4.9 \pm 6.3$ \\
\hline Kentucky bluegrass (Poa pratensis L.) & $18.2 \pm 21.5$ & $22.3 \pm 16.1$ \\
\hline Indian grass (Sorghastrum nutans (L.) Nash) & $0.8 \pm 1.9$ & $5.7 \pm 11.9$ \\
\hline reed canary grass (Spartina pectinata Link) & $4.3 \pm 7.4$ & $3.4 \pm 5.5$ \\
\hline sedges (Carex L. spp. ${ }^{1}$ ) & $11.1 \pm 9.2$ & $15.3 \pm 11.5$ \\
\hline Total Shrub Cover & $14.2 \pm 14.6$ & $11.3 \pm 16.9$ \\
\hline lead plant (Amorpha canescens Pursh) & $0.1 \pm 0.1$ & $1.1 \pm 2.4$ \\
\hline white sage (Artemisia ludoviciana Nutt.) & $0.0 \pm 0.1$ & $1.1 \pm 4.4$ \\
\hline willows (Salix L. spp. ${ }^{2}$ ) & $11.9 \pm 12.3$ & $7.2 \pm 11.3$ \\
\hline
\end{tabular}

\section{Results}

\section{Associated Vegetation}

Orchid and non-orchid swales did not differ significantly $(\mathrm{P}>0.05)$ in total plant canopy cover, litter cover, forbs, total graminoids, shrubs or bare ground (Table 1). Cover of wild licorice (Glycyrrhiza lepidota) (plant authorities are found in Table 1) was lower $(\mathrm{P}=0.03)$ in orchid swales and cover of hedge-nettle (Stachys palustris) was higher $(\mathrm{P}=0.002)$ in orchid swales. Leafy spurge (Euphorbia esula) was present in both swale types. Cover of Baltic rush (Juncus balticus) was higher $(\mathrm{P}=0.01)$ on orchid swales compared to non-orchid swales. Kentucky bluegrass (Poa pratensis) and willows, including Salix exigua and $S$. bebbiana, were common on both swale types with similar (P > $0.05)$ cover values.

\section{Soil Moisture}

Surface soil moisture was consistently higher in orchid swales than in non-orchid swales (Table 2). July $1992(\mathrm{P}=0.004)$, August $1992(\mathrm{P}=0.002)$, and June 1993 $(\mathrm{P}=0.05)$ soil moisture in the top $2 \mathrm{~cm}$ of soil was higher in orchid swales

Table 2. Average ( \pm SD) gravimetric soil moisture for orchid and non-orchid swales in July and August 1992 and June 1993, by depth on the Sheyenne National Grassland.

\begin{tabular}{lllll}
\hline \hline Depth & Swale Type & July 1992 & August 1992 & June 1993 \\
\hline$(\mathrm{cm})$ & & $-\cdots-\cdots-\cdots$ & $-\cdots$ \\
$0-2$ & orchid & $26.3 \pm 7.7 * *$ & $23.9 \pm 8.9 * *$ & $51.9 \pm 17.0$ \\
& non-orchid & $21.2 \pm 6.0$ & $16.3 \pm 13.0$ & $44.8 \pm 15.5$ \\
$2-10$ & orchid & $30.3 \pm 11.5$ & $30.6 \pm 13.7 *$ & $41.3 \pm 15.0$ \\
& non-orchid & $26.9 \pm 13.2$ & $24.9 \pm 14.3$ & $34.9 \pm 15.7$ \\
$10-20$ & orchid & $19.9 \pm 5.4$ & $20.0 \pm 6.9$ & $25.0 \pm 6.0$ \\
& non-orchid & $20.4 \pm 9.9$ & $18.3 \pm 9.6$ & $24.3 \pm 8.5$ \\
$20-30$ & orchid & $14.5 \pm 3.9$ & $14.9 \pm 11.3$ & $20.4 \pm 4.5$ \\
& non-orchid & $13.8 \pm 5.1$ & $12.7 \pm 4.9$ & $18.3 \pm 5.5$ \\
\hline
\end{tabular}

** Orchid and non-orchid swales different $(\mathrm{P}<0.01)$

*Orchid and non-orchid swales different $(\mathrm{P}<0.05)$ clay loam, and loam. The percentage sand $(70 \%, \pm 11.7 \mathrm{SD}-$ orchid; $70 \% \pm 14 \mathrm{SD}$ non-orchid), silt $(16 \% \pm 7.1 \mathrm{SD}$ - orchid; $15 \% \pm 7$ SD - non-orchid), and clay (14\%, \pm 5.6 SD - orchid; $15 \% \pm 7.4$ SD - nonorchid) did not differ $(\mathrm{P}>0.05)$ between orchid and non-orchid swales.
(24-52\%), compared to non-orchid swales $(16-45 \%)$. In addition, soil moisture at the 2 - to $10-\mathrm{cm}$ depth was higher in orchid swales than in non-orchid swales in August 1992. Soil moisture at greater depths $(10-30 \mathrm{~cm})$ did not differ between orchid and non-orchid swales.

\section{Standing Water}

Standing water depths in 1993 varied greatly within and among swales. In July, the water depth in orchid swales averaged $28.3 \mathrm{~cm}( \pm 18.9 \mathrm{SD})$, compared to an average of $13.3 \mathrm{~cm}( \pm 12.7 \mathrm{SD})(\mathrm{P}=0.001)$ in non-orchid swales. The maximum depth of standing water in orchid and non-orchid swales was $80 \mathrm{~cm}$ and $43.6 \mathrm{~cm}$, respectively. The depth of standing water in August 1993 declined in most swales, but remained significantly higher $(\mathrm{P}=0.007)$ in orchid swales $(13.5 \mathrm{~cm} \pm 12.2 \mathrm{SD})$ compared to non-orchid swales $(4.3 \mathrm{~cm} \pm$ 6.7 SD). Maximum water depths in August were 45.0 and $31.8 \mathrm{~cm}$, respectively, for orchid and non-orchid swales; but some swales of both types had no standing water in 1993.

\section{Soil Chemistry and Texture}

With the exception of soluble magnesium, soil chemistry was similar in the 2 swale types (Table 3). Within the upper 10 $\mathrm{cm}$ of soil, soluble magnesium was significantly higher $(\mathrm{P}=0.002)$ in non-orchid swales than in orchid swales. In general, the upper $10 \mathrm{~cm}$ of soil in all swales could be described as a neutral to slightly alkaline, fertile sandy loam. The range of soil textures included sand, loamy sand, sandy 
Table 3. Average ( \pm SD) nitrogen $(N)$, organic matter $(\mathrm{OM})$, calcium carbonate $\left(\mathrm{CaCO}_{3}\right)$, pH, electrical conductivity (EC), phosphate phosphorous $\left(\mathrm{PO}_{4}\right) \mathrm{P}$, nitrate $\left(\mathrm{NO}_{3}\right) \mathrm{N}$, potassium $(\mathrm{K})$, sodium $(\mathrm{Na})$, magnesium (Mg), calcium (Ca), sulfur (S), and water at saturation for orchid and non-orchid swale soils on the Sheyenne National Grassland, 1992.

\begin{tabular}{lcc}
\hline \hline \multirow{2}{*}{ Analysis } & \multicolumn{2}{c}{ Swale Type } \\
\cline { 2 - 3 } $\mathrm{N}(\%)$ & Orchid & Non-orchid \\
$\mathrm{OM}(\%)$ & $6.5 \pm 0.4$ & $0.5 \pm 0.4$ \\
$\mathrm{CaCO}_{3}(\%)$ & $9.3 \pm 8.1$ & $8.8 \pm 8.4$ \\
$\mathrm{pH}$ & $7.7 \pm 0.2$ & $7.6 \pm 0.5$ \\
$\mathrm{EC}(\mathrm{ds} / \mathrm{m})$ & $0.7 \pm 0.1$ & $0.7 \pm 0.2$ \\
$\mathrm{PO}_{4} \mathrm{P}(\mathrm{mg} / \mathrm{kg})$ & $8.7 \pm 5.0$ & $8.2 \pm 3.1$ \\
$\mathrm{NO}{ }_{3} \mathrm{~N}(\mathrm{mg} / \mathrm{kg})$ & $13.2 \pm 9.5$ & $11.2 \pm 7.7$ \\
$\mathrm{~K}(\mathrm{meq} / \mathrm{l})$ & $0.3 \pm 0.3$ & $0.4 \pm 0.3$ \\
$\mathrm{Na}(\mathrm{meq} / \mathrm{l})$ & $0.5 \pm 0.2$ & $0.4 \pm 0.2$ \\
$\mathrm{Mg}(\mathrm{meq} / \mathrm{l})$ & $2.1 \pm 0.8 * *$ & $2.9 \pm 1.3$ \\
$\mathrm{Ca}(\mathrm{meq} / \mathrm{l})$ & $4.9 \pm 0.8$ & $4.3 \pm 1.5$ \\
$\mathrm{~S}(\mathrm{mg} / \mathrm{kg})$ & $20.4 \pm 12.0$ & $18.5 \pm 8.2$ \\
$\mathrm{H}_{2} 0$ at saturation $(\%)$ & $87.9 \pm 35.2$ & $78.5 \pm 30.6$ \\
\hline
\end{tabular}

** Orchid and non-orchid swales different $(\mathrm{P}<0.01)$.

\section{Logistic Regression}

The logistic regression analysis included 36 of the 51 independent variables (Table 4). These variables made sense biologically and were not highly correlated with each other. Percent cover of Baltic rush was the most useful variable in differentiating swales that support orchids from swales that did not (Table 5). With just Baltic rush in the model, the equation correctly classified $68 \%$ of orchid swales and $63 \%$ of non-orchid swales (Table 6). The addition of cover of hedge-nettle increased the percentage of swales correctly classified to an average of $71 \%$ for the 2 swale types. The addition of soluble magnesium enhanced the percentage of correctly classified swales to $79 \%$. August soil moisture at the depth of $0-2 \mathrm{~cm}$ was the last variable to enter the equation. The final model correctly classified $84 \%$ of both the orchid and non-orchid swales:

Probability of an orchid swale =

$$
1 /[1+\exp (-1.10+0.60 J U B A
$$$$
+3.53 \mathrm{STPA}-0.23 \mathrm{Mg}+0.32 \mathrm{ASM} 2)] \text { (1) }
$$

where JUBA = Baltic rush canopy cover, STPA = hedge-nettle canopy cover, $\mathrm{Mg}=$ soil magnesium, and ASM2 = August surface soil moisture.

\section{Discussion}

Managers need an understanding of habitat requirements of individual plants, and their relationship with other species and environmental parameters. Managers also need techniques that can be used to

Table 4. Independent variables included ${ }^{1}$ in the logistic regression analysis used to identify those most useful in distinguishing between orchid and non-orchid swales on the Sheyenne National Grassland.

\begin{tabular}{|c|c|}
\hline Cover (\%) of: & Other Variables \\
\hline Total plant canopy & August soil moisture: $0-2 \mathrm{~cm}$ \\
\hline Total forb & August soil moisture: $10-20 \mathrm{~cm}$ \\
\hline Ambrosia psilostachya & June soil moisture: $0-2 \mathrm{~cm}$ \\
\hline Aster simplex & June soil moisture: $20-30 \mathrm{~cm}$ \\
\hline Euphorbia esula & Total N $(\%)$ \\
\hline Euthamia graminifolia & $\mathrm{OM}(\%)$ \\
\hline Fragaria virginiana & $\mathrm{CaCO}_{3}(\%)$ \\
\hline Juncus balticus & $\mathrm{pH}$ \\
\hline Polygonum amphibium & $\mathrm{EC}(\mathrm{ds} / \mathrm{m})$ \\
\hline Solidago canadensis & $\mathrm{PO}_{4}$ (available) $(\mathrm{meq} / \mathrm{l})$ \\
\hline Stachys palustris & $\mathrm{NO}_{3}(\mathrm{meq} / \mathrm{l})$ \\
\hline Litter & K (soluble cation) (meq/l) \\
\hline Total graminoid & $\mathrm{Na}$ (soluble cation) (meq/l) \\
\hline Total Carex spp. & Mg (soluble cation) (meq/l) \\
\hline Calamogrostis stricta & $\mathrm{Ca}$ (soluble cation) (meq/l) \\
\hline Dichanthelium wilcoxianum & S (soluble cation) (meq/1) \\
\hline \multicolumn{2}{|l|}{ Panicum virgatum } \\
\hline \multicolumn{2}{|l|}{ Poa pratensis } \\
\hline \multicolumn{2}{|l|}{ Spartina pectinata } \\
\hline \multicolumn{2}{|l|}{ Total Salix spp. } \\
\hline
\end{tabular}

assess the quality of potential sites so they can alter management in areas likely to support threatened and endangered species or identify sites where reintroductions are more likely to be successful. This study provided a better understanding of the vegetation and soils of sites that supported the threatened western prairie fringed orchid, compared to sites devoid of this plant. We used these data to develop a logistic regression model that allows managers to quickly (and quantitatively) assess the likelihood that a given site will support orchids.

In many respects, the vegetative composition of both swales that supported and did not support orchids was similar, and included mixed grass and sedge meadow species. The vegetative differences between swales that supported orchids and those without orchids were a reflection of moisture conditions. Orchid-supporting swales had higher canopy cover of Baltic rush and hedge-nettle, yet lower cover of wild licorice. Baltic rush often grows in slightly alkaline sites, and along with hedge-nettle, is associated with high moisture habitats such as prairie sloughs, seepages and marshes (Great Plains Flora Association 1986).

We found that soil moisture was important in influencing the distribution of orchids, yet soil chemistry (with the exception of magnesium levels) was a poor indicator of orchid habitat. Swales that supported orchids were characterized by consistently higher surface $(0-2 \mathrm{~cm})$ soil moisture and deeper water in 1993 compared to those swales lacking orchids. Further, surface soil moisture was 1 of 4 variables in the final equation that best distinguished orchid swales from nonorchid swales. These data support Sieg and King's (1995) findings that orchid densities were associated with high surface (0-4 cm depth) soil moisture.

Subsurface moisture $(2-10 \mathrm{~cm})$ may also influence orchid habitat. In another phase of this study, $60 \%$ of the orchids Wolken (1995) examined had their rooting systems entirely within $10 \mathrm{~cm}$ of the surface. Soil moisture below $10 \mathrm{~cm}$ was less important in influencing orchid presence or absence. Similar soil moisture readings below $10 \mathrm{~cm}$ for both swale types indicate that soil moisture levels below the maximum rooting depth $(16 \mathrm{~cm})$ are not as critical as soil moisture levels within the lateral root system range $(2-10 \mathrm{~cm})$.

Unfortunately, this study also verified the presence of invasive species that threaten the quality of orchid habitat on the Sheyenne National Grassland. The 
Table 5. Results of logistic regression analysis of variables characterizing orchid swales and nonorchid swales on the Sheyenne National Grassland, 1992-1993.

\begin{tabular}{llccc}
\hline \hline $\begin{array}{l}\text { Step } \\
\text { number }\end{array}$ & $\begin{array}{c}\text { Variable }^{1} \\
\text { entered }\end{array}$ & $\begin{array}{c}\text { Log } \\
\text { likelihood }\end{array}$ & $\begin{array}{c}\text { Model }^{2} \\
\text { Chi-square }\end{array}$ & $\begin{array}{c}\text { Improvement }^{3} \\
\text { Chi-square }\end{array}$ \\
\hline 1 & JUBA & -26.34 & $10.3^{* *}$ & $10.3^{* *}$ \\
2 & STPA & -21.21 & $18.7^{* *}$ & $8.4^{* *}$ \\
3 & Mg & -17.00 & $25.4^{* *}$ & $6.7^{* *}$ \\
4 & ASM2 & -13.66 & $35.0^{* *}$ & $9.6^{* *}$ \\
\hline
\end{tabular}

JUBA = Juncus balticus canopy cover (\%); STPA = Stachys palustris canopy cover $(\%) ; \mathrm{Mg}=$ soil magnesium (mg/l); ASM2 = 1992 August soil moisture (\%) at a depth of 0-2 cm.

${ }^{2}$ The model chi-square tests the null hypothesis that there is no difference between the constant and the model presented; a small $\mathrm{P}$ value indicates a significant change in the model.

${ }^{3}$ The improvement chi-square tests the null hypothesis that the addition of a variable does not change the model; a small P-value indicates improvement of the model with the addition of that variable.

*** significant at $\mathrm{P}<0.01$ strong presence of Kentucky bluegrass in these swales was consistent with other recent studies (Sieg and King 1995, Sieg and Bjugstad 1994, Bjugstad-Porter 1993). Kentucky bluegrass tends to dominate and out-compete other plants (Reader et al. 1994), and orchid density in some years on the Sheyenne National Grassland was negatively correlated with Kentucky bluegrass cover (Sieg and King 1995). The invasion of leafy spurge, a perennial noxious weed, is a serious threat to orchid habitats on the Sheyenne National Grassland (Sieg and Bjugstad 1994).

Management of existing orchid habitat on the Sheyenne National Grassland should focus on sustaining the moist swales that support the orchid and its key vegetative associates. In the long run, sustaining orchid habitat depends on maintaining the hydrologic regime (U.S. Fish and Wildlife Service 1996). Further, understanding interspecific differences in gross root morphology, mycorrhizal associations and below-ground spatial and nutrient competition between neighboring species may be needed to fully describe the habitat needs of the western prairie fringed orchid (Jastrow and Miller 1993).

The logistic regression equation presented in this paper correctly classified $84 \%$ of 38 swales using 4 variables. By collecting data on the cover of just Baltic rush, which would take about 45 minutes, and entering it in the equation, a land manager could classify $66 \%$ of the swales in this ecoregion as either suitable or unsuitable as orchid habitat. The higher the estimated probability value (e.g., 0.99), the greater the probability the swale will support orchids (Norusis 1990). This technique can be used to prioritize sites for altering management activities such as treating leafy spurge, livestock grazing and prescribed burning. This technique also allows the identification of suitable habitat when attempting to expand an existing population or establish a new one, thus increasing the odds of successfully transplanting plants or germinating seeds on the new site (Holsinger and Gottlieb 1991).

Although this model is based on presence or absence of orchids, in reality, there
Table 6. Classification rates at each step of a forward step-wise logistic regression model based on 19 orchid and 19 non-orchid swales on the Sheyenne National Grassland. Classification rates were estimated using "leave-one-out" cross-validation (Efron and Tibshirani 1993).

\begin{tabular}{|c|c|c|c|c|c|}
\hline \multirow[b]{2}{*}{ Step } & \multirow[b]{2}{*}{ Variable $^{\mathrm{a}}$} & \multirow{2}{*}{$\begin{array}{l}\text { Observed } \\
\text { Swale type }\end{array}$} & \multicolumn{2}{|c|}{ Number predicted } & \multirow{2}{*}{$\begin{array}{c}\text { Classification } \\
\text { rate }\end{array}$} \\
\hline & & & non-orchid & orchid & \\
\hline \multirow[t]{3}{*}{1} & JUBA & orchid & 13 & 6 & 68.4 \\
\hline & & non-orchid & 7 & 12 & 63.2 \\
\hline & & AVERAGE & & & 65.8 \\
\hline \multirow[t]{3}{*}{2} & STPA & orchid & 14 & 5 & 73.7 \\
\hline & & non-orchid & 6 & 13 & 68.4 \\
\hline & & AVERAGE & & & 71.1 \\
\hline \multirow[t]{3}{*}{3} & $\mathrm{Mg}$ & orchid & 15 & 4 & 78.9 \\
\hline & & non-orchid & 4 & 15 & 78.9 \\
\hline & & AVERAGE & & & 78.9 \\
\hline \multirow[t]{3}{*}{4} & ASM2 & orchid & 16 & 3 & 84.2 \\
\hline & & non-orchid & 3 & 16 & 84.2 \\
\hline & & AVERAGE & & & 84.2 \\
\hline
\end{tabular}

$\overline{\mathrm{a} J \mathrm{JA}}=$ Juncus balticus canopy cover (\%); STPA = Stachys palustris canopy cover $(\%) ; \mathrm{Mg}=$ soil magnesium (mg/l); ASM2 = 1992 August soil moisture (\%) at a depth of 0-2 cm. is likely a spectrum of suitability that varies in time (Hof et al. 1999). Data from multiple years may increase our ability to model the capacity of the Sheyenne National Grassland landscape to support a metapopulation by assessing whether or not there are suitable, but unoccupied, swales that could be colonized by orchids. In the meantime, this model provides a valuable tool for evaluating potential orchid habitat in this ecoregion. In other ecoregions, or for other rare species, quantitative habitat data could be collected and used in developing similar models.

\section{Literature Cited}

Bjugstad, A.J. and W. Fortune. 1989. The western prairie fringed orchid (Platanthera praeclara): monitoring and research. North Amer. Prairie Conf. 11:197-199.

Bjugstad-Porter, R. 1993. The western prairie fringed orchid (Platanthera praeclara): its response to burning and associated mycorrhizal fungi. M.S. Thesis, Dept. of Range Manage., Univ. Wyoming, Laramie, Wyo.

Daubenmire, R.F. 1959. A canopy-coverage method of vegetational analysis. Northwest Sci. 33:43-66.

Day, P.R. 1965. Particle fractionation and particle size analysis. In: C.A. Black (ed.), Methods of soil analysis. Part $1,1^{\text {st }}$ ed. Agron. 9, Amer. Soc. of Agron., Madison, Wis.

Efron, B. and R.J. Tibshirani. 1993. An Introduction to the bootstrap. Chapman \& Hall, N.Y.

Great Plains Flora Association. 1986. Flora of the Great Plains. Univ. Press of Kansas, Lawrence, Kans.

Greweling, T. and M. Peech. 1960. Chemical soil tests. Cornell Univ. Agr. Exp. Sta. Bull. No. 960.

Hof, J., C. Hull Sieg, M. Bevers. 1999. Spatial and temporal optimization in habitat placement for a threatened plant: the case of the western prairie fringed orchid. Ecol. Model. 115:61-75

Holsinger, K.E. and L.D. Gottlieb. 1991. Conservation of rare and endangered plants: principles and prospects, p. 195-208 In: Falk, D.A and K.E. Holsinger (eds.) Genetics and conservation of rare plants. Oxford Univ. Press, N.Y..

Hosmer, D.W. and S. Lemeshow. 1989. Applied logistic regression. John Wiley \& Sons, New York, N.Y.

Jastrow, J.D. and R.M. Miller. 1993. Neighbor influences on root morphology and mycorrhizal fungus colonization in tallgrass prairie plants. Ecol. 74: 561-569.

Jones, J.B. 1971. Laboratory procedures for the analysis of soils, feed, water, and plant tissue. Soil Testing and Plant Analysis Lab., Athens, Ga. 
Mehta, C.R. and N.R. Patel. 1995. SPSS exact tests 6.1 for windows. SPSS, Inc Chicago, Ill.

Norusis, M.J. 1990. SPSS/PC+ advanced statistics., Ver. 3.0 and 3.1. SPSS, Incorporated, Chicago, Ill.

Olsen, S.R., and L.E. Sommers. 1982. Phosphorous soluble in sodium bicarbonate, In: A.L. Page (ed.), Methods of soil analysis, Part 2, 2nd Edition. Agron. 9, Amer. Soc. of Agron., Madison, Wisc.

Press, S.J. and S. Wilson. 1978. Choosing between logistic regression and discriminant analysis. J. Amer. Statistics Assoc. 73:699-705.

Reader, R.J., S.D. Wilson, J.W. Belcher, I. Wisheu, P.A Keddy, D. Tilman, E.C. Morris, J.B. Grace, J.B. McGraw, H. Olff, R. Turkington, E. Klein, Y. Leung, B. Shipley, R. van Hulst, M.E. Johansson, C. Nilsson, J. Gurevitch, K. Grigulis, and B.E. Beisner. 1994. Plant competition in relation to neighbor biomass: an intercontinental study with Poa pratensis. Ecol. 75: 1753-1760.
Richards, L.A. (ed.). 1954. Diagnosis and improvement of saline and alkali soils. Agr. Handb. \#60. USDA, Washington, D. C.

Samson, F. and F. Knopf. 1994. Prairie conservation in North America. BioScience 44:418-421.

Schemske, D.W., B.C. Husband, M.H. Ruckelshaus, C. Goodwillie, I.M. Parker, and J.G. Bishop. 1994. Evaluating approaches to the conservation of rare and endangered plants. Ecol. 75:584-606.

Sheviak, C.J. and M.L. Bowles. 1986. The prairie fringed orchids: a pollinator-isolated pair. Rhodora 88:267-290.

Sieg, C.H. and A.J. Bjugstad. 1994. Five years of following the western prairie fringed orchid (Platanthera praeclara) on the Sheyenne National Grassland, North Dakota. North Amer. Prairie Conf. 13:141-146.

Sieg, C.H. and R.M. King. 1995. Influence of environmental factors and preliminary demographic analysis of a threatened orchid, Platanthera praeclara. Amer. Midland Natur. 134:61-77.
Sims, J.R. and G. Jackson. 1971. Rapid analysis of soil nitrate with chromotropic acid. Soil Sci. Soc. of Amer. Proc. 35:603-606.

U.S. Fish and Wildlife Service. 1989. Endangered and threatened wildlife and plants; determination of threatened status for Platanthera leucophaea (eastern prairie fringed orchid) and Platanthera praeclara (western prairie fringed orchid). Federal Register 54: 39857-39862.

U.S. Fish and Wildlife Service. 1996. Platanthera praeclara (western prairie fringed orchid) recovery plan. U.S. Fish and Wildlife Service, Ft. Snelling, Minn. 101 p.

Wolken, P.M. 1995. Habitat and life history of the western prairie fringed orchid (Platanthera praeclara). M.S. Thesis, Dept. of Plant, Soil, and Insect Sci., Univ. Wyoming, Laramie, Wyo. 